\title{
Building Customer Citizenship Behavior from Relationship Quality and Perceived Value Perspective in Online Transportation Service
}

\author{
Tatik Suryani ${ }^{1}$, Indra Listyarti ${ }^{2}$ \\ [Management Department, Sekolah Tinggi Ilmu Ekonomi Perbanas Surabaya, Surabaya, Indonesia] \\ tatik@perbanas.ac.id ${ }^{1}$, Indra.listyarti@ perbanas.ac.id ${ }^{2}$
}

Received: $14 / 04 / 2020$.

Reviewed: $21 / 04 / 2020$.

Published: 31/08/2020.

Copyright $\odot 2020$ by the author (et al) and Jurnal Sosial Humaniora (JSH)

*This work is licensed under the Creative

Commons Attribution International License (CC BY 4.0).

http://creativecommons.org/licenses/by/4.0/ Open Access

\begin{abstract}
Subject Area: Marketing
Abstract

Recently, Customer Citizenship behavior (CCB) has become a research focus in marketing. However, not many researches focus on the antecedent of this variable from the marketing behavior perspective. The research objective is to examine the effect of Relationship Quality and Perceived Value on CCB in online transportation services and Customer Satisfaction as the mediation in this relationship. The research involved 400 online transportation customers in Indonesia who used a minimum of three times in this transportation. By using Partial Least Square (PLS), the result found that Relationship Quality has a significant positive effect on Customer Satisfaction and CCB, Perceived Value has a positive significant effect on Customer Satisfaction and has no significant effect CCB. It means that for strengthen $C C B$, online transportation should create customer satisfaction. Research also found that Customer Satisfaction has a positive effect on CCB. The implication of the research is online transportation should improving the relationship quality and value for creating customer satisfaction for strengthening CCB. Customer satisfaction is an important conditions for improving $C C B$.
\end{abstract}

Keywords: Customer Citizenship Behavior (CCB); Relationship Quality; Perceived Value; Customer satisfaction

\section{Introduction}

Intensive competition in online transportation services has caused companies to look for analternative marketing strategy which is less expensive. In Indonesia, there are two biggest market shares for online transportation services that compete closely with each other, namely Gojek and Grab. In addition to other online transportation service companies and conventional transportation services in fighting over the market. They compete through technological sophistication, service variants, convenience, and price. If the company focuses on this strategy, it will be easy to replicate and will also cost a lot. Therefore, this study suggests that the company needs another strategy that is more efficient but satisfying the customer.

One strategy that can be applied is to engage customers voluntarily action in order to help in marketing activities. The voluntary positive behavior of these customers is known as Customer Citizenship Behavior (CCB) which is now a concern of researchers and practitioners in the service sector (Groth, 2005). The importance of CCB in achieving sustainable business performance has been reviewed in several studies. Cheng, Luo, Yen \& Yang in their study stated that CCB encourages customers to voluntarily offer products, provide advice to other customers, and provide feedback to the company (Cheng, Luo, Yen, \& 
Yang, 2016). CCB is proven to provide benefits in protecting companies from problems such as, helping reduce company costs, helping support company improvement, and many others (Zoghbi-manrique-de-lara \& Rodríguez, 2015). Hence, if the company tries to use CCB as its strategy, it is expected that the company will get a number of important benefits to support business performance in the future.

However, the main problem of the company lies in how they can establish CCB for the customer. Several studies have shown that customer satisfaction is an antecedent of CCB (Van Tonder \& De Beer, 2018). Referring to the Social Exchange Theory, customers who feel that they have benefited from the company and are satisfied will reply to the company by having a positive attitude towards the company. Satisfied customers will act willingly to help the company.

In addition to customer satisfaction, a study conducted by Balaji showed that the quality of the relationship had a positive effect on CCB (Balaji, 2014). The higher the quality of the relationship between the company and its customers, the higher the customer satisfaction is, and in turn, will have a positive impact on CCB. The quality of this relationship is important to consider if the other benefits offered by the competing companies are almost similar. The quality of relationships can be a differentiator creating a unique advantage for the services offered. Furthermore, based on the previous studies, the quality of relationships and perceived value proved to play an important role in shaping CCB. Although there have not been many studies on this matter, the study of Cheng et al. shows that the perceived value has a significant effect on CCB (Cheng et al., 2016). The higher the customer perceived value for a product or service the higher customer satisfaction and this encourages him to do CCB.

Based on the available literature and previous studies, a more in-depth study exploring the relationship between variables in the context of online transportation services is very important to be researched. This is because the quality of the relationship and the perception of value from a customer's perspective are important for customers. The quality of relationships created by online service providers and interactions with drivers is important that will affect customer satisfaction. It is expected that high perceived value will encourage customers to do CCB. Therefore, this study aims to examine the effect of relationship quality on satisfaction and CCB and perceived value on customer satisfaction and CCB and analyze the effect of satisfaction on CCB.

\section{Literature Review}

\section{Customer Citizenship Behavior (CCB)}

Customer Citizenship Behavior (CCB) is a voluntary behavior carried out by customers to provide useful information to other customers (Yi, 2013). CCB is a concept derived from Organizational Citizenship Behavior (CCB) (Zhu, Sun, \& Chang, 2016). CCB is characterized by actions taken by customers outside their role as customers.

There are three dimensions of CCB, namely: (1) Recommendations. Recommendations are an action when customers voluntarily provide referrals or recommendations to other customers regarding the perceived benefits associated with a product or service, (2) provide feedback to the company in the hope that the company makes improvements so that its performance becomes better, and (3) helps other 
customers. For example, providing information related to products or services to other customers (Groth, 2005).

From previous studies, Fowler states that CCB might involve two dimensions of organizational citizenship: sportsmanship (willingness to tolerate inevitable inconveniences and impositions of work without complaint; and self-development (voluntary efforts to improve one's knowledge, skills, and abilities, to make more contributions to the organization / larger social entity (Fowler, 2013). In practice, the form of CCB can be varied however only three indicators are chosen for this research. In this research, $\mathrm{CCB}$ is indicated from three behaviors, namely recommendation, giving feedback, and helping other customers.

\section{Relationship Quality, Customer Satisfaction, and CCB}

Although there is still disagreement about the concept of relationship quality, most studies explain that relationship quality involves a process of future customer attitudes and expectations from the relationship between a seller and a buyer. Relationship quality is based on customer evaluations of exchanges. the relationship he has with the company. The quality of the relationship can also be defined as the level of feasibility of a relationship between the company and its customers to meet the needs of customers (Jap, Manolis, \& Weitz, 1999)

A good relationship quality will increase commitment, trust, long-term relationships between customers and the company. Another study on relationship quality states that relationship quality is a multidimensional construct consisting of trust, commitment, minimal opportunism, and satisfaction (Nguyen \& Nguyen, 2010). Customers expect good quality relationships provided by the company. Customers who feel the quality of a good relationship with the company will feel more satisfied with the company's products and services. The research shows that the quality of the relationship has a significant effect on customer satisfaction (Santouridis \& Veraki, 2017)

The relationship between the customer and the company can be explained by the Social Exchange Theory which shows that in interactions there is an exchange where each party expects the most unequal giving and receiving. Customers will reward companies if they get benefits whose value is in line with their expectations. If the customer has good relationship quality, it means that the company can provide according to or exceed customer expectations, the quality of the relationship will improve (Bennett \& Barkensjo, 2005). The impact of this good relationship quality is that customers will be more deeply involved in the company's services and intend to voluntarily help the company and also other customers, by providing information related to the company (Xie, Poon, \& Zhang, 2017). Customers tend to do positive behaviors, such as volunteering to help company services (Customer Citizenship Behavior) and providing information related to company services to other customers. Balaji's research results showed that relationship quality has positively significantly affected CCB (Balaji, 2014). In other words, improving the quality of the relationship between companies and customers has a positive effect on CCB. Van Tonder \& de Beer's research shows that customer satisfaction has a positive significant effect on CCB [B4]. Customer satisfaction mediated partially the relationship between relationship quality and CCB (Van Tonder \& De 
Beer, 2018). It is indicated by the result of Variance Accounted For (VAF) that the value between $20 \%$ $80 \%$.

\section{Perceived value, customer satisfaction, and $\mathrm{CCB}$}

When customers interact with the company, then they will judge and feel the benefits of the goods or services it receives. Perceived value is a comprehensive assessment by consumers of the usefulness of a product or service it receives (Chiu, Won, \& Bae, 2019). The value perceived by the customer is considered as the basis for all marketing activities, mainly the benefits of products or services.

Perceived value involved overall value or benefits received by the customer in the service delivery process carried out by the company. The increasing perceived value will make customers feel more satisfied. Thus, when customers evaluate the perception of higher value, then they will be more satisfied. The study conducted by Ali et al. shows that perceived value is the key that drives increased customer satisfaction (Ali, Leifu, Yasirrafiq, \& Hassan, 2015)

When customers are satisfied, it will have an impact on positive customer behavior. Customers who have felt the positive value of service will show customer citizenship behavior to others. This is in line with the social exchange theory because customers feel obliged to reciprocate and get involved in helping companies (Cheng et al., 2016). Consumers will behave voluntarily to the company which can be an asset for the company. Research results from Cheng et al. show that perceived value has a significant effect on Customer Citizenship Behavior (Cheng et al., 2016).

Based on the study of theory and previous research, the following framework is constructed in this research is presented in Figure1.

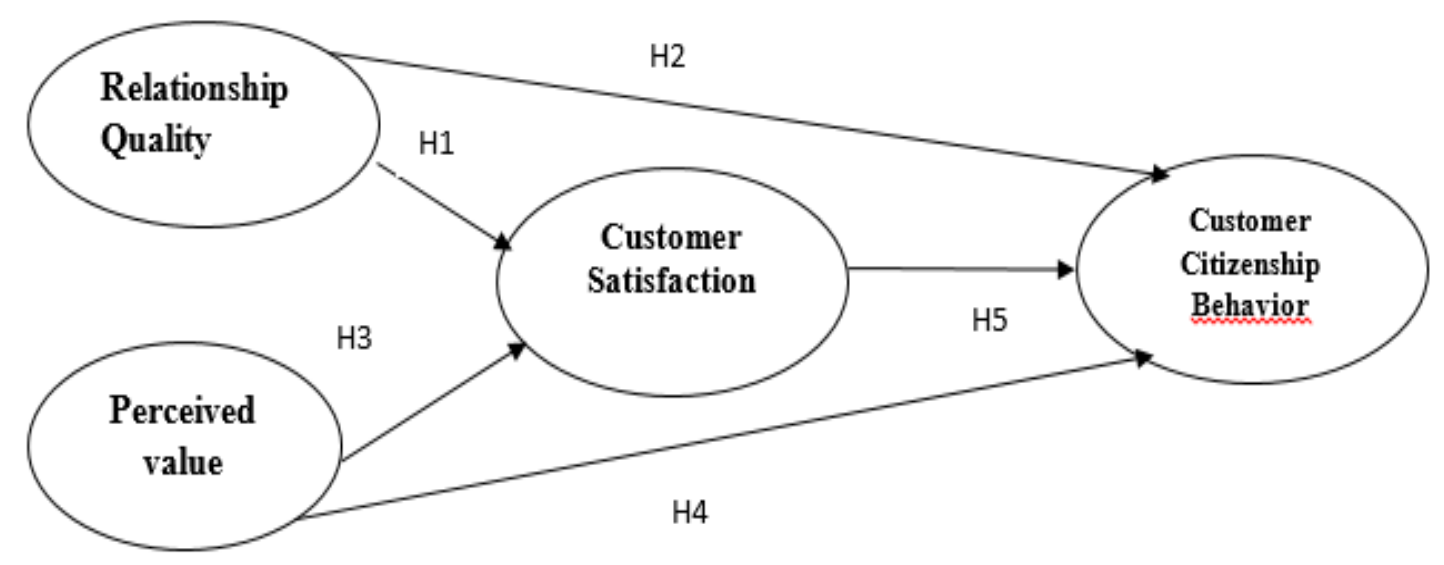

Figure 1. Conceptual Framework

\section{Hypothesis}

According to the framework, the following research hypotheses are presented below:

H1: Relationship quality has a significant positive effect on customer satisfaction in online transportation services. 
H2: Relationship quality has a significant positive effect on CCB in online transportation services

H3: Perceived value has a significant positive effect on customer satisfaction of online transportation services.

H4: Perceived value has a significant positive effect on CCB in online transportation services.

H5: Customer satisfaction has a significant positive effect on CCB in online transportation services

\section{Methodology}

\section{Research design}

This research is survey research that uses a questionnaire as a primary data collection tool. This study is regarded as a causal study that aims to investigate the effect of relationship quality and perceived value on customer satisfaction and CCB users of online transportation services (Sugiyono, 2012)

\section{Population and sample}

The population in this study are online transportation service users in Surabaya and Jakarta with 400 respondents. The sample was selected using a judgmental sampling technique with the criteria of using online transportation services for more than 6 (six) months.

\section{Variable and Measurement}

In this study, the independent variables are Relationship Quality, and Perceived Value, while the mediating variables are Customer Satisfaction and the dependent variable is CCB.

a. Relationship Quality is a customer evaluation of two-way communication made by the company with customers and the company's ability to help solve customer problems.

b. Perceived value is the value perceived and received by customers after using online transportation services in the form of utilitarian values, hedonic values, impressions and expectations of online transportation services (Cheng et al., 2016).

c. Customer Satisfaction is an evaluation conducted by customers after they are using online transportation services (Van Tonder \& De Beer, 2018)

d. Customer Citizenship Behavior is a voluntary behavior conducted by a customer to help companies in the form of providing recommendations, feedback, and helping other customers (Groth, 2005; Van Tonder \& De Beer, 2018)

All variables are measured on a Likert scale with 5 alternative answers from Very Disagree equals to 1 scale, disagree 2 scale, neutral 3 scale, agree 4 scale, and strongly Agree 5 scale. All instruments are tested for validity and reliability. Convergent and discriminant validity test results for all item indicators show values> 0.7, so they are declared valid (Hair, Babin, Andeson, \& Black, 2018). In the overall discriminant validity test shows the AVE value for Relationship Quality is 0.625 , Perceived value is 0.632 , Customer satisfaction is 0.632 , and CCB has AVE value of 0.633. This coefficient value> 0.6 is valid [18]. The reliability test results using Composite Reliability and Cronbach Alpha results show that all instruments are reliable.

Table 1. Reliability Analysis Result 


\begin{tabular}{lccc}
\hline \multicolumn{1}{c}{ Variables } & $\begin{array}{c}\text { Composite Reliability } \\
\text { Coefficient }\end{array}$ & $\begin{array}{c}\text { Cronbach } \\
\text { Alpha }\end{array}$ & Results \\
\hline Relationship Quality & 0,856 & 0,778 & Reliable \\
Perceived Value & 0,897 & 0,855 & Reliable \\
Customer Satisfaction & 0,894 & 0,852 & Reliable \\
Customer Citizenship Behavior $(\mathrm{CCB})$ & 0.931 & 0.914 & Reliable \\
\hline
\end{tabular}

\section{Data analysis technique}

The collected data is analyzed using descriptive statistics and Partial Least Square (PLS) regression analysis to facilitate the processing of data on many independent variables and the symptoms of multicollinearity on these variables.

\section{Result and Discussion}

This study involved 400 respondents from 430 questionnaires distributed to Gojek and Grabs transportation service users from Jakarta and Surabaya who were online transportation users for more than 6 months. The response rate of this study was $69,76 \%$. Characteristics of respondents in terms of their gender are following: 55, 75\% are women, and 44, 25\% are men. The education: are as follows: $30 \%$ have a high school education, $20 \%$ have diploma education, 38.5\% have undergraduate education, $6.5 \%$ graduate, and $5 \%$ outside of these (SMP, SD). Lastly, 5\% of the respondent's income is less than 3.5 million, $69 \%$ is between 3.5 to 7 million, and $10 \%$ is above 7 million.

Table 2. Descriptive analysis results on Research Variables

\begin{tabular}{lll}
\hline Variables & Mean & Scale \\
\hline Relationship Quality & 4,052 & Agree \\
Perceived Value & 3,812 & Agree \\
Customer satisfaction & 4,279 & Strongly Agree \\
CCB & 4,022 & Agree \\
\hline
\end{tabular}

Based on the categorization by taking into account the average score, the score between $1.00<\mathrm{a} \leq 1.80$ belongs to the category of Strongly Disagree; $1.81<\mathrm{a} \leq 2.60$ including the Disagree category; $2.61<\mathrm{a} \leq$ 3.40 including the Doubtful category; $3.41<\mathrm{a} \leq 4.20$ included in the Agree category; and a range of 4.21 $<\mathrm{a} \leq 5.00$ including Strongly Agree. This means that online transportation customers are very satisfied with the services provided. In terms of relationship quality and perceived value, CCB is also high. Thus, from the aspect of marketing performance, especially when viewed from relationship quality, perceived value, satisfaction, and CB are good. The results of the analysis carried out show in Table 3.

Table 3 Structural Equation Modelling on Path Coefficients 


\begin{tabular}{ccc}
\hline Relationship & Loading & P Value \\
\hline $\mathrm{RQ} \rightarrow \mathrm{CS}$ & 0.404 & $<0.001$ \\
$\mathrm{RQ} \rightarrow \mathrm{CCB}$ & 0.140 & 0.023 \\
$\mathrm{PV} \rightarrow \mathrm{CS}$ & 0.348 & $<0.001$ \\
$\mathrm{PV} \rightarrow \mathrm{CCB}$ & 0.075 & 0.146 \\
$\mathrm{CS} \rightarrow \mathrm{CCB}$ & 0.372 & $<0.001$ \\
\hline
\end{tabular}

The effect of relationship quality on customer satisfaction and CCB in online transportation services

The analysis shows that relationship quality has a significant positive effect on customer satisfaction. From a customer perspective, good relationship quality is a critical success factor for company service. When using online transportation services, a company's ability which is fast (Santouridis \& Veraki, 2017) and accurate response company's ability to help customers face problems is very important to satisfy customers. This study shows that the quality aspects of relationships established by transportation companies are good, therefore customers are satisfied. The results of the research support previous studies which show that relationship quality has a positive effect on customer satisfaction (Santouridis \& Veraki, 2017)

Superior quality relationships are needed to create long-term relationships (Balaji, 2014). If the quality of the relationship with the customer is better, then customer satisfaction will increase. The results of this study which show that relationship quality has a positive effect on CS reinforces the argument that relationship quality is seen as the main factor in shaping attitudes, which in this context is a positive attitude in the form of satisfaction with the online transportation services provider (Sánchez-Garcia, Moliner-Tena, Callarisa-Fiol, \& Rodríguez-Artola, 2007). This study also strengthens studies on online (motorcycle) transportation services with the same results (Aisy \& Suryani, 2019).

Furthermore, this study also found that the quality of the relationship has positive significant effect on CCB. This shows that the higher the quality of the relationship, the stronger Customer Citizenship Behavior (CCB). These results are consistent with the result of Balaji (Balaji, 2014). In the context of the research conducted, communication management of online transportation to customers through the system is already good and it is followed by the driver who has communication skill and ability to solve the customer problem.

\section{The effect of perceived value on customer satisfaction and CCB in online transportation services}

The analysis shows that perceived value significantly influences on customer satisfaction. These results are in line with the results of a previous study by Cheng et al. (Cheng et al., 2016). In marketing, value is what customers are looking for. Customers will perceive the value provided by the company. Companies that are perceived to provide superior value will be chosen by the customer. This perceived value is formed from a comprehensive assessment of the usefulness of a product or service based on the performance of the product or service received and felt by the customer (Chiu et al., 2019). The higher the perceived value of the customer, the higher the customer satisfaction. 
The results of this study are in line with several studies in different industries that show the positive influence of perceived value on customer satisfaction (Ali et al., 2015). Users of online transportation services who perceive the benefits received as greater than the costs incurred, thus it becomes a perceived value. When the customer has a good perceived value, then it will make the customers satisfied (SánchezGarcia et al., 2007)

The effect of perceived value on CCB in this study was not significantly positive. This result is not consistent with the Cheng et al. studies (2016) (Cheng et al., 2016). When customers feel they get value for the purchase of goods or services, consumers will satisfy, but it does not affect directly to behave positively to the company. Even though the customer gets satisfaction but this condition does not stimulate enough for them to help other customers, give feedback voluntarily to the company and recommend other customers to buy the services.

What is the role of satisfaction in the context of the relationship between perceived value and CCB? The results show that customer satisfaction as a mediating variable the influence of perceived value on CCB. CCB will increase if customers satisfy and it's because of good relationship quality from services providers to their customers. The effect of relationship quality on CCB occurs when there is customer satisfaction. Thus, when satisfaction increases, CCB will increase. Satisfied customers will encourage customers to try to be more involved in helping the company and have voluntary intentions to help the company and other customers (Xie et al., 2017).

\section{The effect of Customer satisfaction on CCB}

The result found that customer satisfaction has a positive effect significantly on CCB. It's relevant to the Social Exchange Theory explanation that in social interaction (service provider - customer), both parties, especially customer calculates the benefits during the interaction. If customers perceive that they got like what they hope or more, they will satisfy. Satisfaction stimulates them to behave positive behavior for the service provider. Satisfaction is necessary conditions for energizing customers to help a company by helping other customers, giving feedback and advice for a company, and giving recommendations voluntarily to other customers (Groth, 2005; Zhu et al., 2016).

The implication of this finding, it's very important for strengthening customer satisfaction. I broader concept how to create it, is not only mention relationship quality and perceive value, but also other antecedents of satisfaction such as quality services, service image (brand image), social support and reputation (Xie et al., 2017); (Zhu et al., 2016). In this studies the ability of relationship quality and perceive value to determine customer satisfaction only $36 \%$.

\section{Conclusion}

This research could answer the role of relationship quality and perceived value on influencing customer satisfaction. This study shows that the better of relationship quality, the stronger the perceived value of the customer on transportation online services. In this research, customer satisfaction as a partially 
mediating variable the impact of relationship quality on CCB. This study was also found the direct effect of perceived value on customer satisfaction, but has not a significant effect on CCB. It means that customer satisfaction is necessary conditions for building and strengthening CCB.

The results of this study reinforce previous research which states the importance of relationship quality and perceived value in shaping customer positive attitudes in the long run. CCB as a form of positive customer behavior that supports long-term relationships with service companies. The implication of this finding is that online transportation companies should communicate well with their customers not only online but also with personnel involved in providing services to customers. This is important for the creation of good quality relationships with customers. Another thing that is also important to do is to strive for superior value to customers, both in terms of economic, social, and emotional benefits.

\section{Acknowledgement}

Thanks for this grant to Research and Community Service of Sekolah Tinggi Ilmu Ekonomi Perbanas Surabaya

\section{Bibliography}

Aisy, A. ., \& Suryani, T. (2019). Persepsi Nilai dan kualitas hubungan terhadapn terhadap CCB dengan kepuasan pelanggan pada transportasi online Grab di Surabaya. Jurnal Nusumba, 4(2), 94-106.

Ali, R., Leifu, G., Yasirrafiq, M., \& Hassan, M. (2015). Role Of Perceived Value, Customer Expectation, Corporate Image And Perceived Service Quality On The Customer Satisfaction. The Journal of Applied Business ResearcH, 31(4), 1425-1436.

Balaji, M. S. (2014). Managing customer citizenship behavior: A relationship perspective. Journal of Strategic Marketing, 22(3), 222-239. https://doi.org/10.1080/0965254X.2013.876076

Bennett, R., \& Barkensjo, A. (2005). Relationship quality, relationship marketing, and client perceptions of the levels of service quality of charitable organisations. Nternational Journal of Service Industry Management, 16(1), 81-106. https://doi.org/10.1108/09564230510587168

Cheng, J. C., Luo, S. J., Yen, C. H., \& Yang, Y. F. (2016). Brand attachment and customer citizenship behaviors. Service Industries Journal, 36(7-8), 263-277. https://doi.org/10.1080/02642069.2016.1186658

Chiu, W., Won, D., \& Bae, J. (2019). Managing Sport and Leisure Customer value co-creation behaviour in fitness centres : how does it influence customers ' value, satisfaction, and repatronage intention? Managing Sport and Leisure, O(0), 1-13. https://doi.org/10.1080/23750472.2019.1579666

Fowler, J. G. (2013). Customer Citizenship Behavior: An Expanded Theoretical Understanding Department of Marketing and Economics. International Journal of Business and Social Science, 4(5), 1-9.

Groth, M. (2005). Customers as Good Soldiers: Examining Citizenship Behaviors in Internet Service Deliveries. Journal of Management, 31(7), 7-27. https://doi.org/10.1177/0149206304271375 
Hair, J. ., Babin, B. ., Andeson, R. ., \& Black, W. . (2018). Hair, J.F Babin, B.J Andeson, R.E Black, W.C. New York: Cengage.

Jap, S. ., Manolis, C., \& Weitz, B. (1999). Relationship quality and buyer - seller interactions in channels of distribution. Journal of Business Research, 46, 303-313.

Nguyen, T. T. M., \& Nguyen, T. D. (2010). Learning to build quality business relationships in export markets : evidence from Vietnamese exporters. Asia Pacific Business Review, (October 2014), 37-41. https://doi.org/10.1080/13602380802280009

Sánchez-Garcia, J., Moliner-Tena, M. A., Callarisa-Fiol, L., \& Rodríguez-Artola, R. M. (2007). Relationship quality of an establishment and perceived value of a purchase. Service Industries Journal, 27(2), 151-174. https://doi.org/10.1080/02642060601122710

Santouridis, I., \& Veraki, A. (2017). Total Quality Management \& Business Excellence Customer relationship management and customer satisfaction : the mediating role of relationship quality. Total Quality Management \& Business Excellence, 3363(28 (9-10)), 1122-1133. https://doi.org/10.1080/14783363.2017.1303889

Sugiyono. (2012). Metode Penelitian Kuantitatif, Kualitatif, dan R\&D. Bandung.

Van Tonder, E., \& De Beer, L. T. (2018). New perspectives on the role of customer satisfaction and commitment in promoting customer citizenship behaviours. South African Journal of Economic and Management Sciences, 21(1), 1-11. https://doi.org/10.4102/sajems.v21i1.1894

Xie, L., Poon, P., \& Zhang, W. (2017). Article information: Brand Experience and Customer Citizenship Behavior : The Role of Brand Relationship Quality Abstract. Journal of Consumer Marketting, 34(3), 1-30. https://doi.org/10.1108/JCM-02-2016-1726

Yi, Y. (2013). The Impact of Other Customers on Customer Citizenship Behavior. Psychology and Marketing, 30(4), 341-356. https://doi.org/10.1002/mar

Zhu, D. H., Sun, H., \& Chang, Y. P. (2016). Effect of social support on customer satisfaction and citizenship behavior in online brand communities: The moderating role of support source. Journal of Retailing and Consumer Services, 31, 287-293. https://doi.org/10.1016/j.jretconser.2016.04.013

Zoghbi-manrique-de-lara, P., \& Rodríguez, T. F. E. (2015). HOTELS ' FAIR TREATMENT OF STAFF AND SERVICE SATISFACTION AS CAUSES OF CUSTOMER CITIZENSHIP BEHAVIOR ( CCIB ). The2015WEIInternationalAcademic ConferenceProceedings, 181-183. 